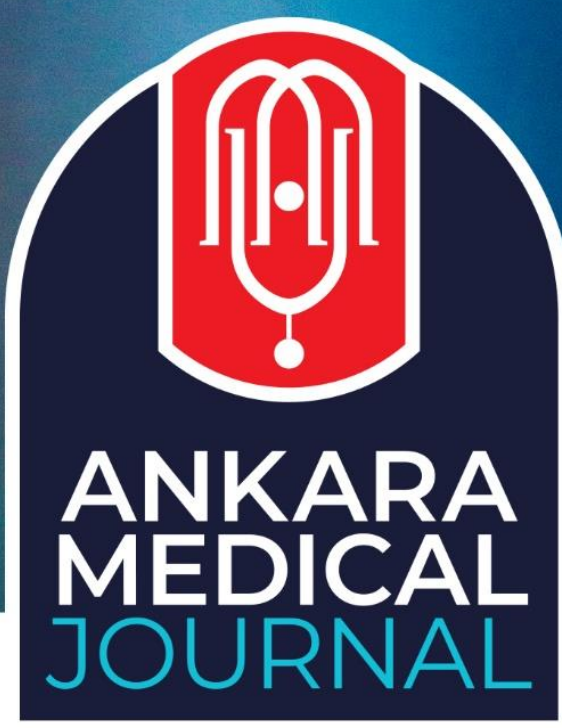

Research Article

Ankara Med J, 2021;(1):22-34 // đot 10.5505/amj.2021.59862

\title{
FOOD ADDICTION PREVALENCE AND RELATED FACTORS AMONG PEOPLE WITH OBESITY: A HOSPITAL-BASED STUDY
}

OBEZ BİREYLERDE YEME BAĞIMLILIĞI VE İLISSTILİ FAKTÖRLER: HASTANE TABANLI BİR ÇALIŞMA

(D) Hacer Hicran Mutlu1, (D) Mehmet Sargın

${ }^{1}$ Department of Family Medicine, Istanbul Medeniyet University, Istanbul

Yazıșma Adresi / Correspondence:

Dr. Öğr. Üyesi Hacer Hicran Mutlu (e-mail: hicranbeyca@hotmail.com)

Geliş Tarihi (Submitted): 03.11.2020 // Kabul Tarihi (Accepted): 31.12.2020

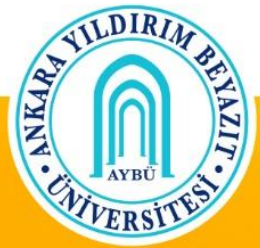

Ankara Yildırım Beyazıt University Faculty of Medicine Department of Family Medicine 


\title{
Öz
}

Amaç: Yeme bağımlılı̆̆ı, son zamanlarda çok tartışılan ve obeziteye neden olan non-homeostatik bir davranıştır. $\mathrm{Bu}$ çalışmada obezite polikliniğimize başvuran bireylerde yeme bağımlılığı sıklığı ve ilişkili faktörleri saptamayı amaçladık.

Materyal ve Metot: 6 aylık zaman diliminde, bir eğitim ve araştırma hastanesi obezite polikliniğine başvuran ve çalışmamıza katılmayı kabul ettiğine dair yazılı onam veren 202 kişiye Yale Yeme Bağımlılığı Ölçeği ve Depresyon, Anksiyete, Stres-21 Ölçeği doldurtuldu. Bütün örneklemdeki yeme bağımlılığı oranı ve bu iki grubun özellikleri arasındaki farklar değerlendirildi.

Bulgular: Çalışmamıza katılan kişilerdeki yeme bağımlılı̆̆ı oranının \%35,10 olduğu tespit edildi. Yeme bağımlılığı olan ve olmayan gruplar arasında yaş, cinsiyet, sigara içme durumu, çocukluk çağında ve ailede obezite varlığı ve egzersiz alışkanlığı açısından fark bulunamadı. Yeme bağımlılığı olan grubun vücut kütle indeksi (VKI) olmayan gruba göre anlamlı olarak daha yüksek bulundu. Depresyon, anksiyete ve stres skoru yeme bağımlılı̆̆ı olan grupta anlamlı olarak daha yüksekti.

Sonuç: Çalışmamamızda, obez bireylerde yeme bağımlılığı oranının yüksek olduğu sonucuna vardık. Bu nedenle, yeme bağımlılığının erken dönemde tanı alması ve tedavi edilmesinin obezite tedavisine önemli katkısı olacağını düşünmekteyiz.

Anahtar Kelimeler: Beslenme ve yeme bozuklukları, bağımlı davranış, depresyon, anksiyete, obezite.

\begin{abstract}
Objectives: Food addiction which is a non-homeostatic behavior that contributes to obesity is a highly discussed issue recently. In the present study, we aimed to determine the prevalence of food addiction among obese people and related factors who applied to our obesity outpatient clinic.

Materials and Methods: Yale Food Addiction Scale (YFAS) and Depression, Anxiety, Stress Scale (DASS)-21 were applied to the 202 participants admitted to a Training and Research Hospital obesity outpatient clinic within 6 months who gave written consent. The patients were divided into two groups as individuals with and without food addiction. The prevalence of food addiction in the total sample and the difference between the two groups were evaluated.

Results: The prevalence of food addiction among participants was $35.10 \%$. There were no significant differences between the groups with and without food addiction in terms of age, gender, smoking status, having a history of childhood obesity, a family history of obesity, and exercising habit. The Body Mass Index (BMI) of the group with food addiction was significantly higher than the group without food addiction. The depression, anxiety, and stress scores of the participants with food addiction were significantly higher than those without food addiction.

Conclusion: In this study, it has appeared that food addiction is prevalent among obese individuals. For this reason, we consider that early diagnosis and treatment of this disorder will make a significant contribution to obesity treatment.
\end{abstract}

Keywords: Feeding and eating disorder, addictive behavior, depression, anxiety, obesity. 


\section{Introduction}

Obesity has become an epidemic globally, affecting millions of people around the world. Obesity is a threat to human health, as it is associated with various co-morbidities. ${ }^{1}$ Despite a wide variety of current treatment options, obese individuals still fail to lose weight. Therefore, the aetiological reasons leading to obesity and regarding potential treatment options have been a matter of curiosity in recent times. ${ }^{2,3}$

The primary determinant of obesity is considered to be dysregulated eating behavior. ${ }^{4,5}$ There is a compromise between the energy requirement and expenditure under normal physiological conditions. Hormones, like ghrelin, leptin, and insulin, regulate homeostatic mechanisms mediating food intake which the weight maintenance is provided by this balance. ${ }^{6,7}$ Obesity is triggered when this balance is disturbed. ${ }^{2}$

It is known that non-homeostatic factors other than mentioned above, so-called hedonic factors, may impact food intake. There is growing evidence for easy access to high-calorie, highly palatable foods, and energy-dense leads to overeating and obesity. Due to these highly palatable foods' hedonic characteristics, the increase in their intake stimulates brain reward regions, and increased dopaminergic discharge promotes craving for these foods similar to alcohol and substance addiction. ${ }^{2,6}$ It has been presented that prolonged exposure to palatable food reduces baseline dopamine levels developing tolerance, subsequently leading to a craving for that food. ${ }^{8}$

"Food addiction" is a behavioral addiction type characterized by an uncontrollable expenditure of palatable foods beyond metabolism's energy requirements. Another definition of food addiction is physical and/or psychological addiction to high sugar, high fat, and highly palatable foods. Food addiction is accompanied by food cravings, binge eating, consequently obesity.4,9

The food addiction concept is not a new term. The addictive potential of highly palatable foods like chocolate was defined as early as the 1890s, and the food addiction term was used since the 1950 s. $^{10,11}$ The neurobehavioral issues determined in obesity are not limited to food addiction; however, researchers have reported that several neurobiological variables resembling addiction are observed in obese individuals. Accordingly, as the prevalence of obesity increases, food addiction has started to attract more attention. ${ }^{12,13}$

In the Diagnostic and Statistical Manual of Mental Disorders (DSM-5), behavioral addictions are recognized as disorders in the substance-related and addictive disorders chapter. Although the only behavioral disorder accepted as an addiction is gambling disorder in DSM 5, food addiction is expected to be recognized as an addictive disorder shortly. ${ }^{14}$ 
In the present study, we aimed to investigate the prevalence of food addiction among obese people who applied to our obesity outpatient clinic and the relationship between sociodemographic factors, depression, anxiety, stress levels, and food addiction in obese people.

\section{Materials and Methods}

\section{Participants and study design}

The present study was conducted between 01.04.2019-01.10.2019 in a Training and Research Hospital Obesity outpatient clinic. Among the patients admitted to the outpatient clinic consecutively, those volunteering to participate in the study and who have given written consent were included in the study. The patients whose $\mathrm{BMI}<30 \mathrm{~kg} / \mathrm{m}^{2}$ were excluded.

\section{Instruments}

Demographic Information Form: It was developed by the researchers within the scope of the research to collect some demographic information of the participants. Age, gender, smoking habit, history of childhood obesity, obesity in the family, exercising habit, and the number of meals eaten per day, were asked face-to-face in the demographic information form.

\section{Anthropometric measurements}

The height of each patient was measured with a stadiometer (SECA) without shoes. The weight of each patient was measured with a bio-impedance analysis device (TANITA MC 780-MA, Tokyo, Japan). Body Mass Index (BMI) was calculated with the Quetelet index $(\mathrm{kg} / \mathrm{m} 2)$.

The Yale Food Addiction Scale (YFAS): The scale was developed by Gearhardt et al. based on the Diagnostic and Statistical Manual of Mental Disorders-IV (DSM-IV) criteria for substance dependence. Gearhardt et al. adapted these criteria for 'food addiction ${ }^{15}$.' The validity and the reliability of the scale into Turkish were performed by Bayraktar et al in 2012. It consists of 26 questions and the most craved foods are asked in the questionnaire The scale is scored by the symptom count. Score 1 is considered for meeting each criterion in the past 12 months and total scores ranged from 0 to 7.16

The Depression, Anxiety and Stress Scale (DASS)-21: The scale was developed by Lovibond et al in $1995^{17}$. The Turkish validity and reliability of the scale were performed by Yıldırım et al. It consists of 21 questions which are designed to measure negative emotional states over the past week in three categories: depression, anxiety, and stress ${ }^{18}$. Higher scores show more severe emotional distress. 
The patients were divided into two groups as individuals with and without food addiction according to YFAS. The prevalence of food addiction in the total sample and the differences between the two groups were evaluated.

\section{Statistical methods}

Data analyses were performed with the statistical software SPSS for IBM, version 25.0 (SPSS, Inc., Chicago, IL). Normally distributed data were shown as mean $\pm \mathrm{SD}$, and the data that were not normally distributed were presented as median, minimum and maximum values. Significant differences of normally distributed data were assessed using a t-test, and significant differences of not normally distributed data were analyzed using the Mann-Whitney U test. Categorical data were expressed as percentages. A regression analysis was performed to test if there is a correlation between BMI and DASS-depression, anxiety, and stress scores in individuals with and without food addiction. The dependent variable was BMI and the independent variables were DASSdepression, anxiety, and stress scores. $\mathrm{P}$ value $<0.05$ was considered as statistically significant

\section{Results}

Table 1 shows the characteristics of the total sample including with and without food addiction. The mean age of the total sample was $45.9 \pm 13.4$ years, $87.60 \%$ of the participants were female and the participants' median BMI was $34.45 \mathrm{~kg} / \mathrm{m}^{2}$.

The most prevalent comorbidity was hypertension (28.20\%), followed by diabetes (19.80 \%), cardiovascular disease (7.90\%), chronic lung disease (6.90\%), obstructive sleep apnea syndrome (3.0\%), and rheumatic disease $(1.0 \%)$. When the relationship between the co-morbidities and food addiction was analyzed, it was found that there was no relationship between diabetes, hypertension, cardiovascular disease, chronic lung disease, and food addiction ( $\mathrm{p}=0.258 ; \mathrm{p}=0.991 ; \mathrm{p}=0.376 ; \mathrm{p}=0.963$, respectively).

The prevalence of food addiction was $35.10 \%(n=71)$. There were no significant differences between groups with and without food addiction in terms of age, gender, smoking status, having childhood obesity, and family history of obesity and exercising habit. The BMI of the group with food addiction was significantly higher than the group without food addiction $(\mathrm{p}=0.031)$ (Table 1).

The rate of individuals who were not addicted to any food was $12.40 \%$. There was no significant difference regarding craving for any food between the groups (Table 2).

The most craved foods in the sample were shown in Table 2 . The addiction to pastry (39.40\% vs $24.40 \%$ ), pasta (46.50\% vs $17.70 \%$ ), rice (35.20\% vs $16.80 \%$ ), pizza/lahmacun (36.60\% vs $19.10 \%$ ), cola/soda (28.20 
$\%$ vs $16.0 \%$ ) was significantly higher in the individuals with food addiction than without food addiction (Table 2).

The classification of the participants according to depression scores were shown in Table 3.

Participants with normal depression, anxiety, and stress median scores were significantly lower in patients who had a food addiction. At the same time participants with extremely severe depression, anxiety, and stress median scores were significantly higher in patients who had food addiction (Table 3). Depression, anxiety, and stress median scores of the individuals with food addiction were significantly higher than those without food addiction. (Table 4).

Table 1. The characteristics of total sample including with and without food addiction

\begin{tabular}{|c|c|c|c|c|c|}
\hline & & $\begin{array}{l}\text { The group with } \\
\text { food addiction } \\
\text { n=71 }\end{array}$ & $\begin{array}{l}\text { The group } \\
\text { without food } \\
\text { addiction } \\
n=131\end{array}$ & $\begin{array}{c}\text { Total } \\
\mathrm{n}=202\end{array}$ & $\mathbf{p}$ \\
\hline Age (years) N & $\mathrm{In} \pm \mathrm{SD}$ & $43.70 \pm 11.40$ & $47.00 \pm 14.20$ & $45.90 \pm 13.40$ & 0.071 \\
\hline & Female \% (n) & $90.10(64)$ & $86.30(113)$ & 87.60 (177) & \\
\hline Gender & Male \% (n) & $9.90(7)$ & $13.70(18)$ & $12.40(25)$ & $0.4 \angle 5$ \\
\hline $\begin{array}{l}\text { Body Mass } \\
\text { (min-max) }\end{array}$ & lex $\left(\mathrm{kg} / \mathrm{m}^{2}\right)$ Median & $35.20(30-48.90)$ & $34.00(30-52.50)$ & $34.45(30-52.50)$ & 0.031 \\
\hline Smoker \% (n & & $23.90(17)$ & $16.80(22)$ & 19.40 (39) & 0.230 \\
\hline Childhood Ob & ity \% (n) & $32.40(23)$ & $26.00(34)$ & $28.20(57)$ & 0.333 \\
\hline Number of $\mathrm{m}$ & s/day & $2.60 \pm 0.70$ & $2.60 \pm 0.70$ & $2.60 \pm 6.70$ & 0.844 \\
\hline $\begin{array}{l}\text { Presence of } \mathrm{f} \\
\%(\mathrm{n})\end{array}$ & ily history of obesity & $70.40(50)$ & $67.90(89)$ & $68.80(139)$ & 0.774 \\
\hline Exercising & 30 minutes/week & $64.80(46)$ & $73.30(96)$ & $70.608142)$ & \\
\hline Habit \% (n) & $\begin{array}{l}\text { Three times at least } \\
30 \text { minutes/week }\end{array}$ & 26.80 (19) & $13.70(18)$ & $18.30(37)$ & 0.310 \\
\hline & $\begin{array}{l}\text { Five times at least } \\
30 \text { minutes/week }\end{array}$ & $8.50(6)$ & $12.20(16)$ & $10.90(22)$ & \\
\hline
\end{tabular}

The correlation between BMI, DASS-depression, anxiety, and stress scores according to food addiction presence were analyzed and it was found that there were correlations between BMI and DASS-depression, anxiety, and stress scores in persons without food addiction ( $r=0.203, p=0.020 ; r=0.313, p<0.001 ; r=0.290$, 
$\mathrm{p}=0.001$, respectively). On the other hand, there was not detected any correlations in terms of these parameters in individuals with food addiction ( $\mathrm{r}=0.029, \mathrm{p}=0.808 ; \mathrm{r}=-0.073, \mathrm{p}=0.544 ; \mathrm{r}=0.007, \mathrm{p}=0.954)$. The scatter plots of the associations between BMI and depression, anxiety scores are shown in Figures 1, 2, and 3.

Table 2. The most craved foods of the total sample including with and without food addiction

\begin{tabular}{|c|c|c|c|c|}
\hline & $\begin{array}{c}\text { Participants with } \\
\text { food addiction } \\
\text { n=71 }\end{array}$ & $\begin{array}{c}\text { Participants } \\
\text { without food } \\
\text { addiction } n=131\end{array}$ & $\begin{array}{c}\text { Total } \\
n=202\end{array}$ & $\mathbf{p}$ \\
\hline Ice-cream \% (n) & $29.60(21)$ & $20.60(27)$ & $23.80(48)$ & 0.153 \\
\hline Chocolate \% (n) & $42.30(30)$ & $34.40(45)$ & $37.10(75)$ & 0.267 \\
\hline Apple \% (n) & $8.50(6)$ & $9.90(13)$ & $9.40(19)$ & 0.732 \\
\hline Cauliflower \% (n) & $7.00(5)$ & $3.80(5)$ & $5.00(10)$ & 0.313 \\
\hline Cookie/Biscuit \% (n) & $26.80(19)$ & $26.70(35)$ & $26.70(54)$ & 0.495 \\
\hline Cake \% (n) & $42.30(30)$ & $30.50(40)$ & $34.70(70)$ & 0.179 \\
\hline Sugar \% (n) & $29.60(21)$ & $27.50(36)$ & $28.20(57)$ & 0.752 \\
\hline Doughnut \% (n) & $16.90(12)$ & $13.0(17)$ & $14.40(29)$ & 0.448 \\
\hline Bread \% (n) & $46.50(33)$ & $40.50(53)$ & $42.60(86)$ & 0.409 \\
\hline Pastry \% (n) & $39.40(28)$ & $24.40(32)$ & $29.70(60)$ & 0.026 \\
\hline Lettuce \% (n) & $9.90(7)$ & $6.90(9)$ & $7.90(16)$ & 0.453 \\
\hline Pasta \% (n) & $46.50(33)$ & $17.60(23)$ & $27.70(56)$ & $<0.001$ \\
\hline Strawberry/Cherry/Grape \% (n) & $22.50(16)$ & $18.30(24)$ & $19.80(40)$ & 0.599 \\
\hline Rice $\%(n)$ & $35.20(25)$ & $16.80(22)$ & $23.30(47)$ & 0.003 \\
\hline Cracker \% (n) & $5.60(4)$ & $10.70(14)$ & $8.90(18)$ & 0.447 \\
\hline Crisps \% (n) & $21.10(15)$ & $16.0(21)$ & $17.80(36)$ & 0.366 \\
\hline Turkish bagel \% (n) & $31.0(22)$ & $22.10(29)$ & $25.20(51)$ & 0.167 \\
\hline Potato chips \% (n) & $43.70(31)$ & $31.30(41)$ & $35.60(72)$ & 0.075 \\
\hline Carrot \% (n) & $4.20(3)$ & $8.40(11)$ & $6.90(14)$ & 0.088 \\
\hline Meat \% (n) & $23.90(17)$ & $17.60(23)$ & $19.80(40)$ & 0.163 \\
\hline Banana \% (n) & $15.50(11)$ & $9.20(12)$ & $11.40(23)$ & 0.151 \\
\hline Bacon/Sausage \% (n) & $18.30(13)$ & $13.70(18)$ & $15.30(31)$ & 0.264 \\
\hline Hamburger \% (n) & $22.50(16)$ & $13.70(18)$ & $16.80(34)$ & 0.172 \\
\hline Toast/Sandwich \% (n) & $21.10(15)$ & $11.50(15)$ & $14.90(30)$ & 0.059 \\
\hline Pizza/Lahmacun \% (n) & $36.60(26)$ & $19.10(25)$ & $25.20(51)$ & 0.008 \\
\hline Cola/Soda \% (n) & $28.20(20)$ & $16.0(21)$ & $20.30(41)$ & 0.041 \\
\hline Cheese \% (n) & $22.50(16)$ & $15.30(20)$ & $17.80(36)$ & 0.198 \\
\hline No craving for any food \% (n) & $9.90(7)$ & $13.70(18)$ & $12.40(25)$ & 0.424 \\
\hline
\end{tabular}


Table 3. The relationship between participants' depression, anxiety and stress scores and food addiction*

\begin{tabular}{|c|c|c|c|c|c|}
\hline & & $\begin{array}{c}\text { Participants } \\
\text { with food } \\
\text { addiction } \\
\mathrm{n}=71\end{array}$ & $\begin{array}{c}\text { Participants } \\
\text { without food } \\
\text { addiction } \\
\text { n=131 }\end{array}$ & $\begin{array}{c}\text { Total } \\
\mathrm{n}=202\end{array}$ & $\mathbf{p}$ \\
\hline \multirow{5}{*}{$\begin{array}{l}\text { Classification of } \\
\text { participants according to } \\
\text { depression scores \% (n) }\end{array}$} & Normal & $46.50(33)_{\mathrm{b}}$ & $64.10(84)_{a}$ & $57.90(117)$ & \multirow{5}{*}{0.005} \\
\hline & Mild & $7.00(5)_{\mathrm{a}}$ & $13.70(18)_{\mathrm{a}}$ & $11.40(23)$ & \\
\hline & Moderate & $18.30(13)_{\mathrm{a}}$ & $10.70(14)_{a}$ & $13.40(27)$ & \\
\hline & Severe & $14.10(10)_{\mathrm{a}}$ & $7.60(10)_{\mathrm{a}}$ & $9.90(20)$ & \\
\hline & Extremely severe & $14.10(10)_{\mathrm{b}}$ & $3.80(5)_{\mathrm{a}}$ & $7.40(15)$ & \\
\hline \multirow{5}{*}{$\begin{array}{l}\text { Classification of } \\
\text { participants according to } \\
\text { anxiety scores \% (n) }\end{array}$} & Normal & $26.80(19)_{\mathrm{b}}$ & $55.70(73)_{\mathrm{a}}$ & $45.50(92)$ & \multirow{5}{*}{$<0.001$} \\
\hline & Mild & $5.30(7)_{a}$ & $7.00(5)_{a}$ & $5.90(12)$ & \\
\hline & Moderate & $18.30(13)_{\mathrm{a}}$ & $16.80(22)_{\mathrm{a}}$ & $17.30(35)$ & \\
\hline & Severe & $21.10(15)_{a}$ & $11.50(15)_{\mathrm{a}}$ & $14.90(30)$ & \\
\hline & Extremely severe & $26.80(19)_{\mathrm{b}}$ & $10.70(14)_{a}$ & $16.30(33)$ & \\
\hline \multirow{5}{*}{$\begin{array}{l}\text { Classification of } \\
\text { participants according to } \\
\text { stress scores \% (n) }\end{array}$} & Normal & $33.80(24)_{b}$ & $60.80(79)_{\mathrm{a}}$ & $51.20(103)$ & \multirow{5}{*}{$<0.001$} \\
\hline & Mild & $9.90(7)_{a}$ & $14.60(19)_{\mathrm{a}}$ & $12.90(26)$ & \\
\hline & Moderate & $14.60(19)_{\mathrm{a}}$ & $26.80(19)_{\mathrm{b}}$ & $18.90(38)$ & \\
\hline & Severe & $6.20(8)_{a}$ & $12.70(9)_{\mathrm{a}}$ & $8.50(17)$ & \\
\hline & Extremely severe & $16.90(12)_{\mathrm{b}}$ & $3.80(5)_{a}$ & $8.50(17)$ & \\
\hline
\end{tabular}

${ }^{*}$ Each subscript letter denotes a subset of food addiction categories whose column proportions do not differ significantly from each other at the 0.05 level.

Table 4. The DASS-depression, anxiety and stress scores of the participants including with and without food addiction

\begin{tabular}{|l|c|c|c|c|}
\hline & $\begin{array}{c}\text { Participants with } \\
\text { food addiction } \\
\mathrm{n}=71\end{array}$ & $\begin{array}{c}\text { Participants without } \\
\text { food addiction } \\
\mathrm{n}=131\end{array}$ & $\begin{array}{c}\text { Total } \\
\mathrm{n}=202\end{array}$ & $\mathbf{p}$ \\
\hline $\begin{array}{l}\text { DASS-Depression score } \\
\text { Median (min-max) }\end{array}$ & $10(0-38)$ & $6(0-39)$ & $7.5(0-39)$ & $<0.001$ \\
\hline $\begin{array}{l}\text { DASS-Anxiety score Median } \\
\text { (min-max) }\end{array}$ & $14(0-38)$ & $7(0-42)$ & $9(0-42)$ & $<0.001$ \\
\hline $\begin{array}{l}\text { DASS-Stress score Median } \\
\text { (min-max) }\end{array}$ & $21(0-42)$ & $12(0-41)$ & $14(0-42)$ & $<0.001$ \\
\hline
\end{tabular}




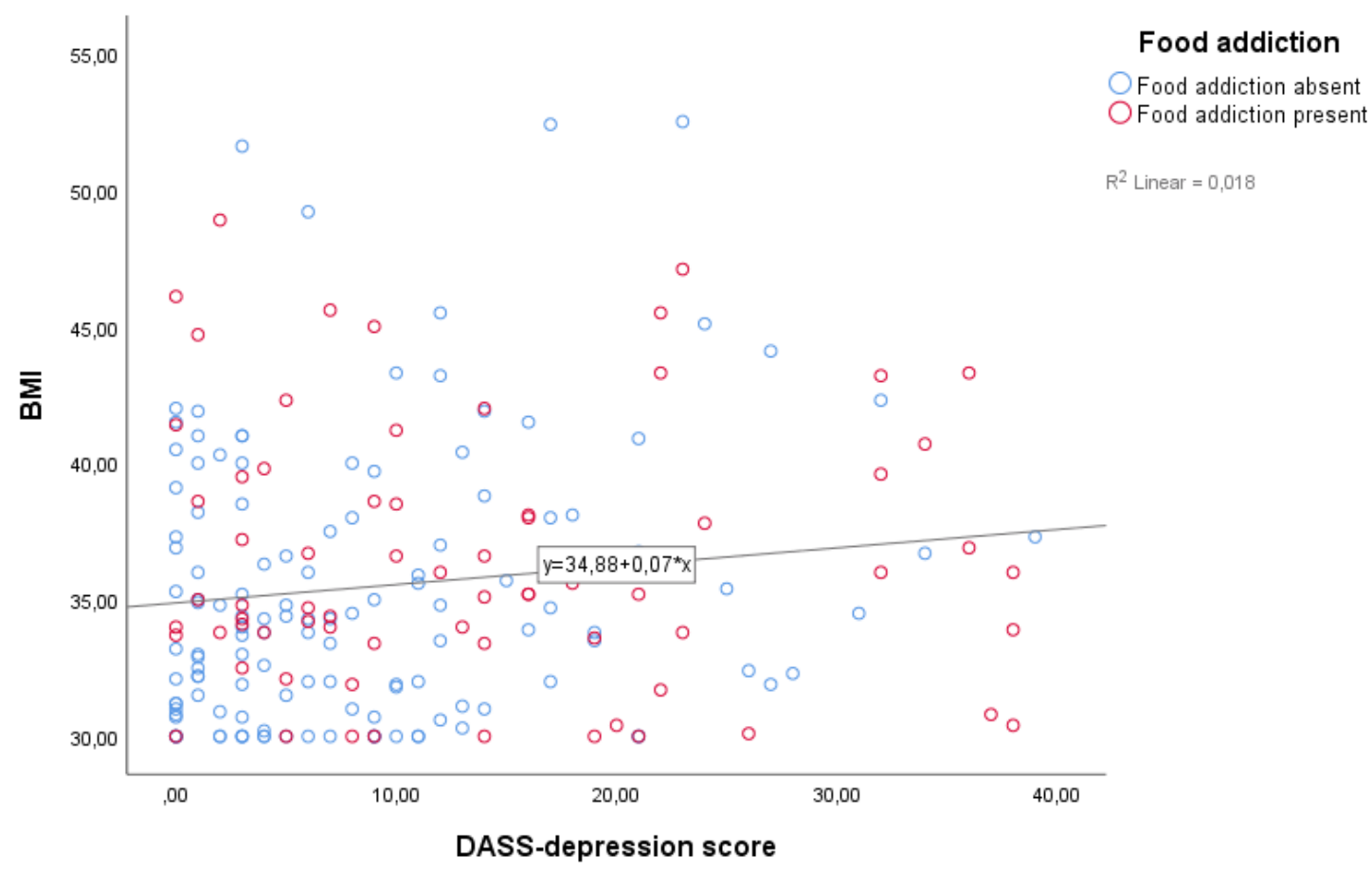

Figure 1. The correlation between BMI and DASS-depression scores in individuals with and without food addiction

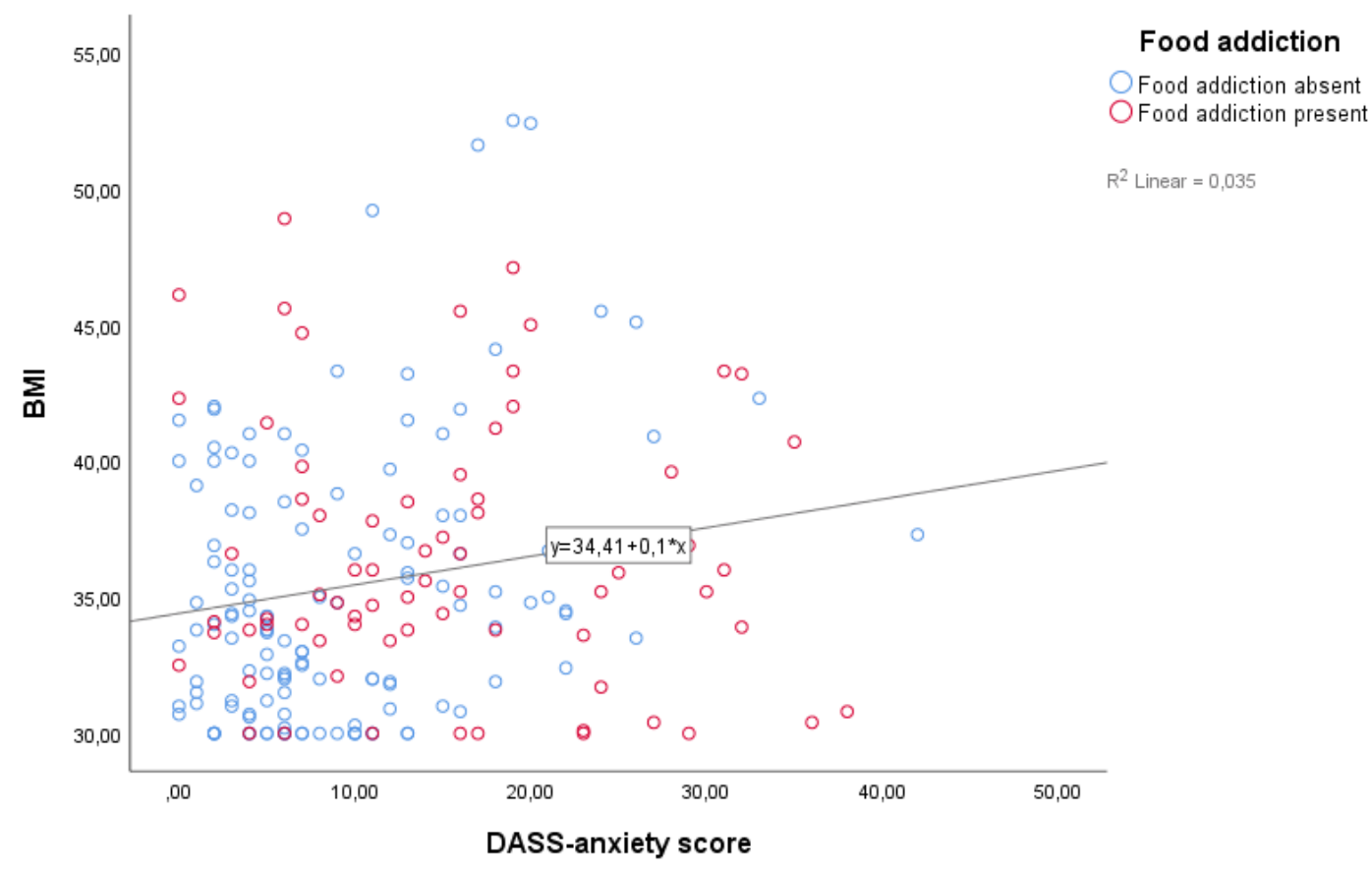

Figure 2. The correlation between BMI and DASS-anxiety scores in individuals with and without food addiction 


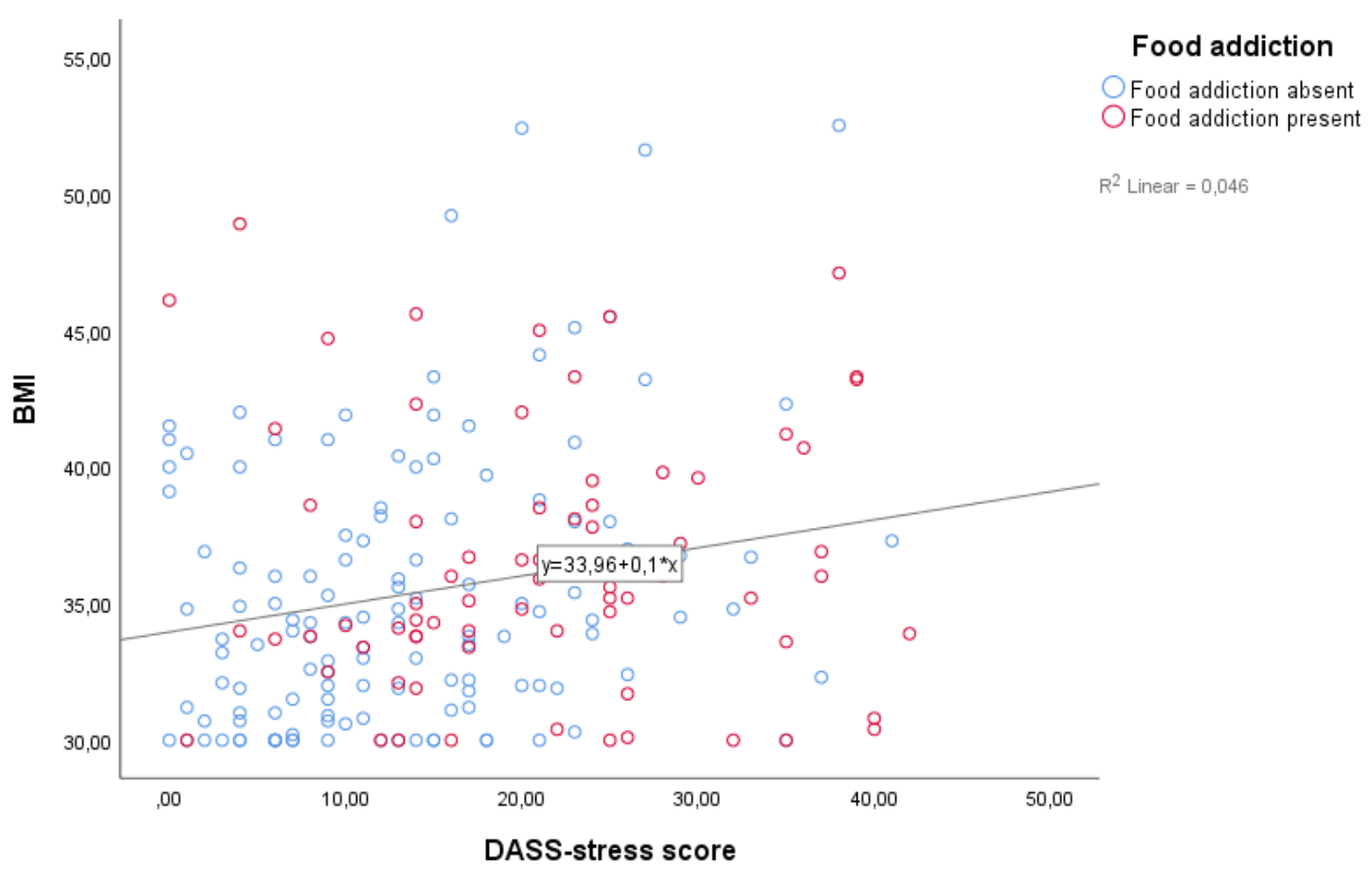

Figure 3. The correlation between BMI and DASS-stress scores in individuals with and without food addiction

\section{Discussion}

Certain foods may stimulate the brain's dopaminergic and endogenous opioid systems (reward circuitry) which leads to a craving for them. This causes excessive consumption of food which is called food addiction. The pathophysiology of food addiction resembles drug and substance addiction. Food addiction contributes to the severity of obesity and there are various studies conducted suggesting higher food craving and addiction is associated with higher BMI. ${ }^{19-21}$ Present study supports this finding; we found that BMI was significantly higher in individuals with food addiction.

Different results were detected in several studies investigating food addiction and related factors. In some studies, no relationship was found between age, gender, current BMI, duration of obesity, age of onset of obesity, and food addiction similar to our study except current BMI.9,13 The authors commented on the reason for not having a relationship between BMI and food addiction as individuals with food addiction develop compensatory strategies despite their compulsive eating behaviors like restricting their daily calorie intake. In the present study BMI of the food-addicted persons was higher, we related this result to the lack of these compensatory strategies in our population. Some other studies showed that women had more tendency to food 
addiction than men, in our study a significant difference was not found between groups in terms of gender, however, the majority of our sample consisted of women. ${ }^{20,22}$

Studies that examined the association of food addiction with other addictive behaviors in adolescents suggested that food addiction was more prevalent in smokers than non-smokers ${ }^{13,20}$ as expected because their addictive mechanisms are similar, however, in the present study no association was found between smoking and food addiction. This may be attributed to the low number of smokers in our study.

The prevalence of food addiction varies between $1.60 \%$ and $24 \%$ in non-obese people and $7.70 \%$ and 56.80 $\%$ in obese people in different populations. ${ }^{13,20,23-27}$ Food addiction prevalence was $35.10 \%$ in the present study which is in harmony with the literature. In recent studies, it has been shown that some food such as sucrose and palatable snack food disrupts hypothalamic-pituitary-adrenal axis stress responses. These results support that some food may affect responses to stress encouraging food addiction owing to the rewarding effects of these foods ${ }^{7}$ and also it has been shown that stress, anxiety, and depression trigger addiction-like eating behaviors in humans in various studies. ${ }^{22}{ }^{28}$ In line with these findings certain foods high in carbohydrates and fat were the most craved and non-processed foods like grain products, fruits or vegetables were the less craved foods in the present study, and depression, anxiety, and stress scores were found to be significantly higher in individuals with food addiction.

High-glycemic-index carbohydrates lead to a rapid shift in blood glucose and insulin levels, like the pharmacokinetics of addictive substances and modify dopamine concentration. Eventually, these characteristics of high-glycemic-index carbohydrates trigger food addiction. ${ }^{29}$ In our study, cravings towards pastry, pasta, rice, pizza, lahmacun which was high in carbohydrates, and cola/soda which was high in sugar were higher in people with food addiction than without food addiction. A study conducted with bariatric surgery patients reported similar results. ${ }^{13}$

Depression and anxiety are the concepts that are associated with food addiction, however, the causality underlying the association between these concepts is not clear. The causality may be bidirectional. Studies regarding psychiatric disorders and food addiction showed that depression and anxiety rates are higher in food addicted people in line with our results. ${ }^{11,13,27}$

One of our interesting findings was the positive correlation between BMI and depression, anxiety, and stress scores in individuals without food addiction, however, the same correlation was not detected in individuals with food addiction. This may be attributed to the hypothesis that palatable food has comforting effects via the dopaminergic reward system. People with food addiction may alleviate their depression, anxiety, or stress levels with palatable foods. Therefore, BMI had not found to be associated with depression, anxiety, and stress. On the other hand, since the rewarding system of the people without food addiction is considered to be different 
from individuals addicted to food, the same alleviation may not have been detected in those without food addiction ${ }^{28}$, consequently a positive correlation between BMI and depression, anxiety and stress may have been determined in the present study.

In conclusion, food addiction is a highly discussed subject in recent literature. This concept is recommended to be accepted as an addictive disorder and treated as an addiction. In our study, food addiction prevalence among obese people was high as was expected. Since losing weight in those with food addiction is hard, early diagnosis and treatment of it becomes more crucial.

\section{Limitations}

Firstly, it was a cross-sectional study, and food addiction and depression, anxiety, stress was diagnosed with a self-reported questionnaire. Second, the sample size of the study was relatively low.

\section{Ethical considerations}

Ethical approval was taken from the Institutional Medical Sciences Review Board. The institutional ethical committee approval number is 2019/0122, obtained on 27.03.2020. All participants provided their informed consent before the study.

\section{Conflict of Interest}

The authors declare no conflict of interest. 


\section{References}

1. Guglielmi V, Sbraccia P. Obesity phenotypes : depot-differences in adipose tissue and their clinical implications. Eat Weight Disord - Stud Anorexia, Bulim Obes 2018;23(1):3-14. (doi:10.1007/s40519017-0467-9)

2. Carter A, Hendrikse J, Lee N, et al. The Neurobiology of "food Addiction" and Its Implications for Obesity Treatment and Policy. Annu Rev Nutr. 2016;36(May):105-28. (doi:10.1146/annurev-nutr-071715050909)

3. Karlsson HK, Tuominen L, Tuulari JJ, et al. Obesity is associated with decreased $\mu$-opioid but unaltered dopamine D2 receptor availability in the brain. J Neurosci 2015;35(9):3959-65. (doi:10.1523/JNEUROSCI.4744-14.2015)

4. Oyekcin D, Deveci A. Etiology of Food Addiction. Psikiyatr Guncel Yaklasimlar - Curr Approaches Psychiatry 2012;4(2):138. (doi:10.5455/cap.20120409)

5. Kafes AY, Ülker S, Sayar GH. Yeme Bağımlılı̆̆ı. Curr Addict Res 2018;2(2):54-8. (doi:10.5455/car.1051537591260)

6. Leigh SJ, Morris MJ. The role of reward circuitry and food addiction in the obesity epidemic: An update. Biol Psychol 2018;131:31-42. (doi:10.1016/j.biopsycho.2016.12.013)

7. Sinha R. Role of addiction and stress neurobiology on food intake and obesity. Biol Psychol 2018;131:513. (doi:10.1016/j.biopsycho.2017.05.001)

8. Volkow ND, Wise RA, Baler R. The dopamine motive system: Implications for drug and food addiction. Nat Rev Neurosci 2017;18(12):741-52. (doi:10.1038/nrn.2017.130)

9. Brunault P, Ducluzeau PH, Courtois R, et al. Food Addiction is Associated with Higher Neuroticism, Lower Conscientiousness, Higher Impulsivity, but Lower Extraversion in Obese Patient Candidates for Bariatric Surgery. Subst Use Misuse 2018;53(11):1919-23. (doi:10.1080/10826084.2018.1433212)

10. Randolph TG. The descriptive features of food addiction. Addictive eating and drinking. Q J Stud Alcohol 1956;17(2):198-224.

11. Meadows A, Nolan LJ, Higgs S. Self-perceived food addiction: Prevalence, predictors, and prognosis. Appetite 2017;114:282-98. (doi:10.1016/j.appet.2017.03.051)

12. Ruddock HK, Orwin M, Boyland EJ, Evans EH, Hardman CA. Obesity stigma: Is the 'food addiction' label feeding the problem? Nutrients 2019;11(9):1-17. (doi:10.3390/nu11092100)

13. Benzerouk F, Gierski F, Ducluzeau PH, et al. Food addiction, in obese patients seeking bariatric surgery, is associated with higher prevalence of current mood and anxiety disorders and past mood disorders. Psychiatry Res 2018;267(5):473-9. (doi:10.1016/j.psychres.2018.05.087)

14. Hauck C, Cook B, Ellrott T. Food addiction, eating addiction and eating disorders. Proc Nutr Soc 2020;79(1):103-12. (doi:10.1017/S0029665119001162) 
15. Gearhardt AN, Corbin WR, Brownell KD. Preliminary validation of the Yale food addiction scale. Appetite 2009;52(2):430-6.

16. Bayraktar F, Erkman F, Kurtulus E. Adaptation study of Yale food addiction Scale. Klin Psikofarmakol Bul 2012;22(1):S38.

17. Lovibond PF, Lovibond SH. The structure of negative emotional states: Comparison of the Depression Anxiety Stress Scales (DASS) with the Beck Depression and Anxiety Inventories. Behav Res Ther 1995;33(3):335-43.

18. Yıldırım A, Boysan M, Kefeli MC. Psychometric properties of the Turkish version of the Depression Anxiety Stress Scale-21 (DASS-21). Br J Guid Counc2018;46(5):582-95.

19. Chao AM, Jastreboff AM, White MA, Grilo CM, Sinha R. Stress, cortisol, and other appetite-related hormones: Prospective prediction of 6-month changes in food cravings and weight. Obesity2017;25(4):713-20.

20. Mies GW, Treur JL, Larsen JK, Halberstadt J, Pasman JA, Vink JM. The prevalence of food addiction in a large sample of adolescents and its association with addictive substances. Appetite 2017;118:97-105. (doi:10.1016/j.appet.2017.08.002)

21. Chen JA, Chen JA, Lee S, Mullin G. Potential role for acupuncture in the treatment of food addiction and obesity. Acupunct Med 2018;36(1):52-5. (doi:10.1136/acupmed-2017-011366)

22. Burrows T, Kay-Lambkin F, Pursey K, Skinner J, Dayas C. Food addiction and associations with mental health symptoms: a systematic review with meta-analysis. J Hum Nutr Diet 2018;31(4):544-72. (doi:10.1111/jhn.12532)

23. Pursey KM, Stanwell P, Gearhardt AN, Collins CE, Burrows TL. The prevalence of food addiction as assessed by the Yale Food Addiction Scale: a systematic review. Nutrients 2014;6(10):4552-90.

24. Torres S, Camacho M, Costa P, et al. Psychometric properties of the Portuguese version of the Yale Food Addiction Scale. Eat Weight Disord Anorexia, Bulim Obes2017;22(2):259-67.

25. Leigh SJ, Morris MJ. The role of reward circuitry and food addiction in the obesity epidemic: An update. Biol Psychol 2018;131:31-42. (doi:10.1016/j.biopsycho.2016.12.013)

26. Filgueiras AR, Pires de Almeida VB, Koch Nogueira PC, et al. Exploring the consumption of ultraprocessed foods and its association with food addiction in overweight children. Appetite 2019;135:13745. (doi:10.1016/j.appet.2018.11.005)

27. Gearhardt AN, White MA, Masheb RM, Morgan PT, Crosby RD, Grilo CM. An examination of the food addiction construct in obese patients with binge eating disorder. Int J Eat Disord 2012;45(5):657-63.

28. Parylak SL, Koob GF, Zorrilla EP. The dark side of food addiction. Physiol Behav 2011;104(1):149-56.

29. Lennerz B, Lennerz JK. Food Addiction, High-Glycemic-Index Carbohydrates, and Obesity. Clin Chem 2018;64(1):64-71. (doi:10.1373/clinchem.2017.273532) 